\title{
Effect of the Contents of Information on the Accountability of the Implementation of the Regional Revenue and Expenditure Budget Against the Re-Election of Incumbents
}

\author{
Darmawati $^{1}$, Gagaring Pagalung ${ }^{2}$, Mediaty $^{3}$ and Ratna Ayu Damayanti ${ }^{4}$
}

${ }^{1}$ Universitas Hasanuddin, Indonesia

${ }^{2}$ Universitas Hasanuddin, Indonesia

${ }^{3}$ Universitas Hasanuddin, Indonesia

${ }^{4}$ Universitas Hasanuddin, Indonesia

\begin{abstract}
This paper aims to explore the extent to which the use of accounting information contented in the report on the performance of local government performance influences voter behavior in the re-election of incumbent regional heads. Based on changes that are recommended by New Public Management (NPM) in the accounting of the public sector to give attention to citizens/voters in order to evaluate the performance of local governments. To do so, start from the following research question: Can the accounting information disclosed by local governments affect the re-election of regional heads in Indonesia? This research is based on agency theory as a grand theory with rational choice theory as a supporting theory. This study uses secondary data from the Directorate General of Financial Management of the Indonesian Republic Finance Ministry (DJPK Ministry of Finance of the Republic of Indonesia) to Realization of Regional Revenue and Expenditure Budget in 2017 and while information data on Unemployment and poverty is obtained from the central statistics agency (https: // www.bps.go.id) and from the official website of the regional government and the respective Regional People's Representative Council. The data while the election was obtained from the official website of the Election Committee https://www.kpu.go.id/ and the official website of each region. This study uses binary logistic regression and uses purposive sampling. Before the regression test, it is examined by using the classical assumption tests. The results showed the contents of accounting information contained in the accountability report. The regional income and expenditure budgeting influences the electability of incumbent re-election, among others, the ratio of regional income to total income, capital expenditure ratio and poverty level positively influences the re-election of incumbents, while the tax revenue ratio the total income, the ratio of total expenditure to total income, the ratio of expenditure on goods and services to total income, and the unemployment rate does not affect the electability of re-election of incumbents. An understanding of information accounting content expressed by the local government voters can make the basis for assessing whether the incumbent regional head is worthy of the opportunity to reign or not. The results of the study provide input to the local government to determine the regulations and policies that will come regarding the accountability of financial statements so that there is no misuse of authority resulting in corruption, collusion, and nepotism.
\end{abstract}

Keywords: Accountability, financial statement, government accounting standards, and accrual

\section{Introduction}

Accounting is a science that experiences developments in the realm of information. Accounting information has developed in the realm of the election of leaders (governors/ mayors/regents) in government. Because accounting plays a role in conveying information, the general goal is to communicate to users who need knowledge of events that have occurred in the past (Ross, 2016: 3). Accounting is a tool that allows citizens/voters to assess the performance of public officials and can be used to communicate the economic effects inherent in decisions made by politicians (Ingram \& Copeland, 1981). Voters need information as a basis for their consideration in determining their political choices. This information provides knowledge for voters to assess and evaluate the 
information they obtain on the performance of regional heads in the previous term of office. On that basis, they used the information as a consideration to make choices in regional head elections.

This study focuses on the relationship of accounting information and socio-economic factors with electability of the re-election of incumbents. The researcher will examine the political consequences of the accountability report of local government implementation 1 year before the election, this study will examine whether voters when choosing to use rational choices by paying attention to the incumbent's performance when they determine their choice. Whether rationally voters will give gifts or rewards for good performance by prospective incumbents and punish fireworks if their performance is poor

According to Waltz (1999) in essence stating that rational choice theory is a tool to make logical conclusions about how humans make decisions, voters are considered rational if during the election the voters consciously and rationally use data and evidence of good conditions for their decision not because of extraordinary things for his future interests. Basically, the rational choice theory is individualistic or individualistic. The results of social and political choices are seen as collective products from the choice of one or several individuals. In addition, Waltz assumes the actor will try to maximize his utility, in other finally, the choice that will be taken is a choice that will bring maximum results to the achievement of his interests.

This research is based on agency theory as a grand theory with rational choice theory as a supporting theory. This study aims to assess whether accounting information has an impact on the re-election of incumbents. To do so, start from the following research question: Does accounting information influence the re-election of incumbents in Indonesia?

Both Rational choice theory and the Principal-agency theory stipulate that a politician will maximize his own welfare. This may be maximizing the sound that benefits the re-election or maximization of privileges that might result from his job position (Buchanan and Tullock, 1965). In democratic countries, elections are the main instrument of citizens/voters to interfere in the election of their country's political power. The ability to influence public policy comes from voting. Voter participation can be seen as a connection that connects citizens and the political system.

Based on agency theory, voters are the attorney/principal (voters) and agents who receive power delegated on behalf of the principal when the official regional head is elected. Rationally agents want to maximize their interests (Jensen and Meckling, 1976; Zimmerman, 1997). In the Downs (1957) political science literature, it presents the following assumptions of economic rationality in decision making: (1) individual voters are motivated by their own economic benefits; (2) individual voters are the basic determinants of political decisions; (3) politicians are motivated by the desire to get and remain in power and (4) to be successful, politicians must make decisions that are perceived by the dominant voter coalition to bring themselves to themselves. Thus, a voter will tend to choose individuals he believes will give him the "highest utility income".

In Indonesia, incumbents still control the victory in most of the political parties held after the direct election of the people. But the concern is not all of these victories were followed by a good performance by the local government led by the incumbent regional head. Rumayya (2015) proves this by showing that the poor performance of regional governments during the incumbent's term does not affect the probability of incumbent re-election. Even further in his research, Rumayya explained that the poor performance of the local government in managing chemistry

Table 1. Results of the incumbent election in 2018

\begin{tabular}{|c|c|c|}
\hline Description & Amount & Presents \\
\hline Win & 90 & $66,2 \%$ \\
\hline Losing & 46 & $33,8 \%$ \\
\hline Total & 136 & $100 \%$ \\
\hline
\end{tabular}

Source: data processed 
Incumbents are considered to have advantages in elections because they are considered good enough for what they do such as campaigns, managing the government, and/or representing the demands or expectations of voters (Trounstine, 2013). In this view, incumbents are high-quality competitors, as stated by Erikson and Wright (2001) that the selection process is designed to choose strong candidates who have the tendency to win and retain their power in the next election. Incumbents have experience and can make policies that benefit their constituents during their tenure (Fiorina, 1989; Cain, et al., 1987). The greater the incumbent's access to resources that are able to satisfy voters, the greater the benefits they have (Carey et al., 2000; Cox and Morgenstern 1993).

Smart voters utilize information from the performance of local governments as their consideration in choosing. Research conducted by Zaller (1992) shows that voters who have well-informed voters will influence their attitudes and political preferences. Voters who have information, are more receptive to, understand, maintain and remember that information when needed (Zaller 1996).

Financial performance accountability, namely accounting has a role in providing information on the performance of local governments reflected in the financial statements of local governments. Ball and Brown (1968) in his research stated that interested users immediately reacted to the existence of published accounting information. He found that the information content of financial statements gave a significant response so that accounting information would affect information users in their decision making. The information content of financial statements provides strong support for the decision usefulness by providing accounting information that encourages the trust of users of accounting information. The information content by Ball and Brown (1968) consists of two types of information, namely good news and bad news. If the information content is good news, it can be ascertained that users of accounting information will react positively, on the contrary, if the information content is bad news then the opposite happens, namely the response from users of negative information.

Accounting information that can be seen by voters from local government financial reports that can influence re-election of incumbents according to Ingram and Copeland (1981) include local revenue divided by total income, tax revenue divided by total income, total expenditure on total income, expenditure on goods and services total income, capital expenditure on total revenue. While information related to determining incumbent re-election is influenced by Unemployment and poverty (Rumayya, 2015) because this can be used as a basis for seeing the level of community welfare so that it is feasible to be chosen because it signals voters that incumbents have worked well in leading the area and re-elected in regional head elections for the following period.

Principal-Agent Theory. Public accountability requires this "Who is responsible and accountable for whom" specification is the main thing from principle-agent theory (Gailmard, 2012). According to Jensen \& Meckling (1976) principals and agents maximize their utility, with that principals and agents, are rational, selfish, and act selfish, Jensen \& Meckling (1976) and Zimmerman (1977) believe that agents do not always act in the interests of the principal. Agency relationships show that there are different interests between agents and principals, and these players are subject to agency fees. Agency costs involve monitoring the costs borne by the principal, and the connection costs (bond costs) incurred by the agent and the remaining losses (Jensen \& Meckling, 1976). Agency problems are inherent in all organizational environments, namely the private sector (between shareholders and managers) and the public sector (between politicians and voters). The welfare of the voters depends on the actions of agents so that each voter has an incentive to monitor the actions of agents (Zimmerman, 1977).

In the public sector, agency relations are contracts between the government as agents and the people as principals. The principal gives authority and authority to the agent to run the government for the public interest. The chosen leader is an agent who is given the mandate from his voters. The principal is the party that gives mandates to other parties, namely agents, to carry out all activities on behalf of the principal in his capacity as a decision maker. The chosen leader is motivated to gain and maintain 
strength. That is why they need to share the sound. Voters are motivated by economic benefits for themselves. The basic assumption of this relationship of voters and elected leaders are rational. Agency theory bases its thinking on differences in information between agents and principals, or asymmetric information that influences the use of accounting systems. In the principal relationship, there is an information gap that can create a conflict of interest between principals and agents (Ponzetto, 2010). Communication that exists between the principal and the agent does not always run effectively. For some reason, the responsibilities imposed on the agent may be unclear or not well understood by the agent. This can be caused by the poor fabric of information between the principal and the agent. Asymmetric information arises when the principal's ability to monitor the behavior and performance of an agent is limited by factors that only the agent knows. Information asymmetry considers the possibility that agents can reduce their performance or hide performance degradation to principals (Amaliyah, 2013).

Asymmetric information can be classified as differences in motivation and differences in knowledge between principals and agents. In some cases, asymmetric information arises as a result of differences in these two factors, namely motivation and knowledge. However, asymmetric information occurs, principals will not have full access to information; which ultimately creates opportunities that are open to agents to gain profits by maintaining certain information so as not to reach the principal.

According to Scott (2003), there are two kinds of information asymmetry, namely:

1) Adverse selection, namely agents and other insiders usually know more about the state of the organization than outside parties who in this case are principals. Facts that might influence the decisions that will be taken by the principal are not delivered by the agent to the principal.

2) Moral hazard, that is, activities carried out by an agent are not entirely known by the principal. So that the agent can act outside the principal's knowledge that violates the law and actually ethically or norms may not be feasible.

The application of the principal-agent theory in this paper is to control elected leaders (governors / mayors/regents) through an electoral institution called the General Election Committee (KPU) which is responsible for the successful implementation of direct elections in the regions (Pemilukada). The election is a means for voters to evaluate governors/ mayors/regents who are incumbents.

Rational Choice Theory (Rational Choice Theory). The rational choice theory is a theory used to answer the best decisions in meeting the interests of actors in their environment (Argueta, 2007). The basic assumption of the rational choice theory is an actor who makes rational choices based on rational actions that he deliberately does to maximize his profits. Who are these actors? The perpetrators of this rational action are politicians, bureaucrats, voters (in various election events) and economic actors (Coleman, 1990). In deciding choices made by actors, this theory seeks to provide an explanation of the optimal choices for decision makers.

One of the fundamental steps in the decentralization policy is the implementation of local elections to elect regional heads (Tjenreng, 2016). This is a feature of a democratic country. General elections are held periodically, including the selection of public officials at the local level (regional heads). No matter how good a government is designed, it cannot be considered democratic if the officials who lead the government are not freely elected by citizens in an open and honest way (Noor, 2015). General elections become the momentum of leadership transition both at the central level and at the regional level. The implementation of decentralization in the political sphere has brought changes and dynamics in each region in Indonesia. National and regional leaders are no longer elected and determined by executive and legislative powers that are centralized but are directly elected by the people as the highest authority in a democratic country. When compared with developed countries such as America and Europe, Indonesia has only implemented democratic principles with direct elections in 2005 after the ratification of Law 32/2004 concerning Regional Government. This further strengthens democratization in Indonesia (Haikal, 2015). Based on this law, regional head elections are no longer carried out in the parliament (House of Representatives) but carried out by all people who fulfill the requirements of the law in each region. 
Direct election by the people will make people understand the democratic and responsible process, provide political education, encourage political parties to recruit cadres in placing candidates as regional heads who have high-quality capabilities and capabilities. In addition, it will strengthen the checks and balances in organizing the government. Finally, the community understands sovereignty. One of the processes of the legitimacy of power is that people as voters will determine their choices by evaluating the performance of candidates for regional heads (Key, 1966). Voters will award or punish incumbents on the basis of incumbent performance in their tenure. This will make incumbents not only diligent but will be motivated to use their initiative in dealing with new or unexpected events that arise between elections. Voters will assess whether the candidate for the regional head has the capability and current performance that is good for himself and for his region. Voters consider the appropriateness of candidates selected to be regional leaders by comparing other candidates, besides voters comparing with previous leaders.

The fact that people act rationally, of course, has been recognized by many sociologists, but they see rational action together with other forms of action that see human action involving rational and nonrational elements. Such actions recognize traditional actions or habits, emotional or effectual actions, and various other forms of action (Asworth, 2012). Furthermore, Asworth (2012) explains rational theory denying the existence of any type of action other than purely rational and calculative. He argues that social actions are motivated by rational actions, as instrumental actions, although they may appear irrational or illogical.

This theory focuses on human actors who have specific goals or intentions. This means that the actor has a goal and the action he does is aimed at trying to obtain that goal. Actors in this theory are considered to have choices, and that these actions are carried out to achieve the objectives in accordance with the level of choice they have. This theory in Coleman's perspective (1990) is a rational action paradigm that integrates with various sociological paradigms.

Coleman said that his approach was based on the methodology of individualism as a micro-level foundation to explain macro-level phenomena. Actors are seen as having choices, goals, and intentions. That is, the actions of the actors will be focused on achieving their goals. This theory is not "The minimal basis for the social system of action is two actors, each controlling resources that attract the attention of others. One person's attention to resources controlled by others is what causes them to engage in actions that need each other ... engage in an active system ... as actors who have a purpose, each aims to maximize the realization of interests that provide interdependent characteristics or systemic characteristics of his or her actions. "

From the explanation above, it can be concluded that a social action consists of elements of actors and resources. An actor is someone who plays an action that has a specific purpose. While resources are something that is attractive to other parties and can be controlled by actors. Coleman then explained that a social system has at least two actors who control the resource. The existence of resources becomes a binder of the nature of mutual need between the two. Actions involving the two actors go to the level of the social system.

Accounting information and voter decisions. In Government Accounting Standards PP 71 of 2010 stated that the financial reporting of local governments should provide information that is useful for users in assessing accountability and making economic, social, and political decisions. Financial statements provide information about income, expenditure, transfers, reserve funds, financing, assets, liabilities, fund acquisitions, and cash flows of an entity. Accounting data is used to interpret past performance and to predict future performance, such information content becomes very important because it will make a lot of difference whether the messages in accounting reports are important or not Bedford \& Baladouni, (1962). Whereas Belzer (1973) suggests, information clears uncertainty, if information is measured then the amount of uncertainty will be lost, therefore the accounting information contained in the financial statements of local governments must be confirmed properly, for this reason, it is needed by the Republic Indonesia Audit Board (BPK RI) to ensure that the information is not biased and the financial performance contained in the LKPD can be justified. 
The assumptions underlying this study of economic rationality in voting (Downs, 1957) include 1). Individual voters are motivated by economic interests; 2 ). Individual voters are the basic determinants of political decisions; 3 ). Politicians are motivated by the desire to get official power; 4). Politicians must make decisions perceived by the dominant coalition of voters to be of personal interest so that they are said to be successful politicians. Besides that, the downs (1957) said that a voter would choose individuals whom he considered could provide high utility income. The decisions that the voters will take will depend on the data available about the incumbent's performance, therefore politicians will try to maximize the policy plan to please their constituents. In addition, the electability of the incumbent returns to the incumbent when advancing again with the same representative or one of them nominates himself in pairs with another person and if both of them advance together and pair up with others then the incumbent is the head of the area.

Theoretical Framework. Previous research that discussed accounting information that could influence the results of local elections was conducted by (Ingram and Copeland, 1981; Feroz and Wilson, 1994; Brusca and Montesinos, 2006; Fernandes, Gomes and Silva, 2012; Rumayya, 2015; Suleman, 2017 ; Cunha, Ferreira, and Fernandes, 2018). Ingram and Copeland (1981) write about the usefulness of accounting information that explains voting decisions in the United Kingdom in 182 cities in 1972 1977 empirically research shows that accounting numbers can provide information to explain voter behavior. Feroz and Wilson (1994) conducted a study in 1983 - 1985 in 220 cities, while Brusca and Montesinos (2006) conducted research in Spain in elections in 1995, 1999 and 2003 in 143 cities.

This research modified their writing. The difference between this research and previous research is that it focuses on direct regional head elections in 2018 with a sample of 146 incumbents in Indonesia. In addition, this study adds several different variables, especially information about the results of evaluating performance accountability from the accountability report for the administration of the incumbent regional head. Empirically this research will prove whether the presentation of information by incumbent governments can affect the electability of the re-election of incumbents.

Every information has information content (Ross, 2016) that is able to influence voter decisions in regional head elections. This information is the performance of local governments that can reflect how the ability of local governments to maximize economic resources that must be carried out in accordance with the law. Information can be in the form of accounting information contained in financial statements produced by local governments as well as non-financial reports in the form of information concerning socio-economics. Financial and non-financial reports are indicators of the success of local governments in the welfare of society seen from the macroeconomic sector as an impact due to the policies made by local governments (Noor, 2015).

Research Hypothesis:

H1. The ratio of regional original income has a positive effect on the electability of the re-election of incumbents.

H2. The ratio of tax revenue to total income has a positive effect on the electability of the re-election of incumbents.

H3. The ratio of total expenditure to total income has a positive effect on the electability of the reelection of incumbents.

H4. The ratio of expenditure on goods and services to total income has a positive effect on the electability of the re-election of incumbents.

H5. The capital expenditure ratio to total income has a positive effect on the electability of the reelection of incumbents.

H6. The unemployment rate has a positive effect on the electability of the re-election of incumbents. H7. The poverty level has a positive effect on the electability of the re-election of incumbents. 


\begin{tabular}{|c|c|}
\hline Variabel Independen & Variabel Dependen \\
\hline \multicolumn{2}{|l|}{ Accounting Information } \\
\hline \multicolumn{2}{|l|}{ - LGRTR (X 1) } \\
\hline \multicolumn{2}{|l|}{ - TTTR (X 2) } \\
\hline - TETR (X 3) & $\vee$ \\
\hline - GSETR (X 4) & \multirow{3}{*}{$\begin{array}{l}\text { Re-election } \\
\text { Incumbent } \\
(Y)\end{array}$} \\
\hline - CETR (X 5) & \\
\hline Social Economic Factor & \\
\hline \multicolumn{2}{|l|}{ - UE (X 6) } \\
\hline - PR (X 7) & \\
\hline & \\
\hline & \\
\hline
\end{tabular}

Figure 1. Research Model

The variables in this study are focused on matters relating to income and expenditure carried out by local governments to see the ability of local governments to make spending decisions capable of being followed by their ability to generate income to cover their spending policies.

Table 2. Variable definitions

\begin{tabular}{|l|l|}
\hline \multicolumn{1}{|c|}{ Variable } & \multicolumn{1}{c|}{ Definition } \\
\hline Re-election Incumbent & Incumbent electability \\
\hline LGRTR & locally-generated revenue/Total Revenue \\
\hline TTTR & Total Tax/Total Revenue \\
\hline TETR & Total Expenses/Total Revenue \\
\hline GSETR & Goods and service Expenses/Total Revenue \\
\hline CETR & Capital Expenses/Total Revenue \\
\hline UE & Unemployment \\
\hline PR & Poverty \\
\hline
\end{tabular}

\section{Research Methodology}

The object of the study was 136 regional governments participating in the regional head elections in 2018, quantitative research methods, explanatory research. 


\section{Result and discussion}

Table 3. Results of Analysis of the Logistic Regression Model

\begin{tabular}{|c|r|r|r|r|}
\hline Variable Independent & Coefficient $(\beta)$ & Z-stat & Significance & Odss Ratio \\
\hline Constant & -1.453 .083 & & & \\
\hline X1 & 84.92311 & 2.563 .177 & 0.0104 & 7,614 \\
\hline X2 & -2.249875 & -0.920996 & 0.3571 & 0,105 \\
\hline X3 & -0.078720 & -0.422900 & 0.6724 & 0,924 \\
\hline X4 & 0.426288 & 1.226 .778 & 0.2199 & 1,532 \\
\hline X5 & 2.264572 & 0.789333 & 0.0099 & 1,303 \\
\hline X6 & -0.982687 & -1.505 .402 & 0.1322 & 0,374 \\
\hline X7 & 2.740064 & 7.710 .796 & 0.0000 & 9,460 \\
\hline Simultaneous tests & & & \\
\hline LR $=76,6915$ & & & \\
\hline Sig $=0.000$
\end{tabular}

Source: calculation results

Then, $y=-1453,08+84.92 X_{1}-2.24 X_{2}-0,07 X_{3}+0.42 X_{4}+2.26 X_{5}-0,98 X_{6}+2.74 X_{7}+e$

which, $y=$ Incumbent Electability

$\mathrm{X}_{1} \quad=$ locally-generated revenue/Total Revenue

$\mathrm{X}_{2}=$ Total Tax/Total Revenue

$\mathrm{X}_{3}=$ Total Expenses/Total Revenue

$\mathrm{X}_{4} \quad=$ Goods and service Expenses/ Total Revenue

$\mathrm{X}_{5} \quad=$ Capital Expenses/Total Revenue

$\mathrm{X}_{6} \quad=$ Unemployment

$\mathrm{X}_{7} \quad=$ Poverty

$\beta=$ Logistic Regression Coefficient

$e^{\beta}=$ Odd Ratio

$\varepsilon \quad=$ Error Variable

The results showed that the ratio of regional income to total income significantly affected the reelection of prospective incumbents, meaning that the higher the local revenue the higher the possibility of incumbents re-elected as well as the higher capital expenditures provided the opportunity for incumbents to be re-elected and the level of poverty has no effect on re-election, broke because even though poverty rises incumbents are still likely to be re-elected, while total tax revenue, total expenditure to total income does not affect the re-election of incumbents, and unemployment does not affect the inclusion of voters election. 


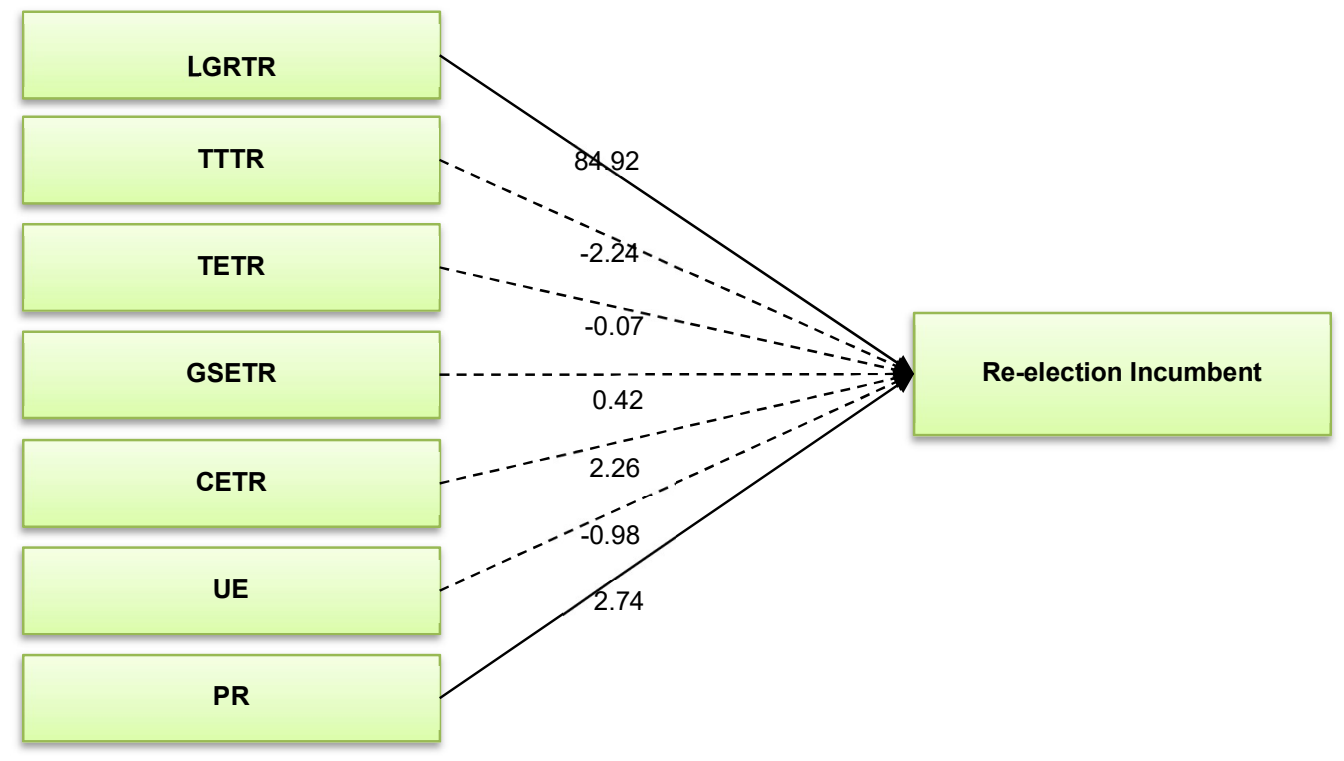

Figure 2. Results of Logistic Regression Analysis

\section{Conclusion}

Based on the results of the study obtained conclusions as follows: Regional Original Income Ratio, capital expenditure to total revenues, and poverty have a significant effect on the re-election of incumbent regional head candidates. While the ratio of tax revenues to total revenues, the ratio of total expenditure to total revenues, expenditure of goods and services to total revenues, and unemployment does not have a significant influence on the re-election of candidates for regional heads.

Acknowledgments. The author would like to thank the Ministry of Research and Technology of the Ministry of Research and Technology for providing research Dissertation grants for the Doctor and the Research and Community Service Institute (LP2M) of Hasanuddin University.

\section{References}

Amaliyah, Tri Handayani. 2013. Suatu Tinjauan Asimetri Informasi dan Implikasinya Terhadap Manajemen Laba. FEB-UNG.

Argueta, Jose Rene. 2007. The Importance of 'Rational' Voters for Electoral Accountability in Highly Institutionalized Party Systems. The University of Pittsburgh. Proquest Information and Learning Company.

Ashworth, Scott. 2012. Electoral Accountability: Recent Theoretical and Empirical Work. The Annual Review of Political Science. University of Chicago, Chicago, Illinois.

Ball, Ray dan Philip Brown. 1968. An Empirical Evaluation of Accounting Income Numbers. Journal of Accounting Research.

Beaver, W. H. (1968). The Information Content of Annual Announcements Earnings. Journal of Accounting Research, 6(1968), 67-92. https://doi.org/10.2307/2490070

Beaver, W., Lambert, R., \& Morse, D. (1980). The information content of security prices. Journal of Accounting and Economics, 2(1), 3-28. https://doi.org/10.1016/0165-4101(80)90013-0

Bedford, N. M., \& Baladouni, V. (1962). A Communication Theory Approach to Accountancy. The Accounting Review, 37(4), 650-659. https://doi.org/10.2307/242352

Brusca, Isabel dan Vicente Montesisos. 2006. Are citizens Significant users of Government Financial Information?.public money \& Management. Journal Compilation,p.205-209

Buchanan, James M dan Gordon Tullock. 1965. "The Calculus of Consent: Logical Foundations Constitutional Democracy" Anne Achor paperback. URL: http://www.econlib.org 
BPS. 2018. Indeks Pembangunan Manusia Tahun 2017.

Cakra, Arbas. 2012. Jalan Terjal Calon Independen pada Pemilukada di Provinsi Aceh. Sofmedia, Jakarta, hlm 31.

Coleman, J. S. 1990. Foundations of Social Theory. Cambridge: Belknap.

Cox, Gary W., Dan Scott Morgenstern. 1993. The Increasing Advantage of Incumbency in the U.S. States." Legislative Studies Quarterly 18: 495-514.

Cunha, Ana Maria, Augusta Ferreira dan Maria Jose Fernandes, (2016). The Influence of Accounting Information in the Re-Election of Portuguese the Mayors. A volume in the Advances in Finance, Accounting, and Economics (AFAE) Book Series. Chapter 6 Information Science Reference (an imprint of IGI Global).

Cunha, Ana Maria, Augusta Ferreira dan Maria Jose Fernandes, (2018). The Influence of Accounting Information and Social Economic Factors in the Re-Election of Portuguese the Mayors. A volume in the Advances in Finance, Accounting, and Economics (AFAE) Book Series. Chapter 19. Information Science Reference (an imprint of IGI Global).

Downs, A. 1957. An Economic Theory of Democracy. New York: Harper \& Row.

Erikson, Robert dan Gerald Wright. 2001. "Voters, Candidates, and Issues in Congressional Elections," in Congress Reconsidered, edited by Lawrence Dodd and Bruce Oppenheimer. 7th Edition, Washington D.C.: CQ Press.

Fernandes, M., Gomes, P., \& Silva, C. (2012). Accounting Information and Voter's Behaviour: Empiri- cal Research in Portuguese Municipalities. Asociación Española da Contabilidad y Administración de Empresas (AECA), XV Encuentro AECA "Nuevos Caminos para Europa: El Papel de las Empresas y los Gobiernos", $106 \mathrm{a}$. Retrievedfromhttp://www.aeca.es/pub/on_line_/comunicaciones_xvencuentroaeca/ cd/106a.pdf

Feroz, E., \& Wilson, E. (1994). Financial Accounting Measures and Mayoral Elections. Financial Ac- countability \& Management, 10(3), 161-174. doi:10.1111/j.1468-0408.1994.tb00006.x

Fiorina, Morris. 1989. Congress: Keystone of the Washington Establishment. 2nd Edition. New Haven: Yale University Press.

Gailmard, F. (2007). Accountability and Principal-Agent Models. Oxford Handbook Of Public Accountability: Oxford University Press.

Haikal, Ali Muhammad, (2015). Peta Petahana dan Potensi Politisasi Birokrasi. Konstitusi dan Demokrasi (KoDe) Inisiatif. www.kodeinisiatif.org

Halim, Abdul. (2013). Akuntansi Sektor Publik: Akuntansi Keuangan Daerah. Edisi Revisi. Jakarta: Salemba Empat.

Ingram, Robert W dan Rinald M. Copeland. (1981). "Municipal Accounting Information and Voting Behavior." The Accounting Review, Vol. 56. No. 4 published by the American Accounting Association.

Jensen, M., \& Meckling, W. (1976). Theory of the Firm: Managerial Behavior, Agency Costs, and Ownership Structure. Journal of Financial Economics, 3(4), 305-360. doi:10.1016/0304405X(76)90026-X

Key, V. O. 1966. The Responsible Electorate. Cambridge: Harvard University

Noor, Henry Faizal, 2015. Ekonomi Publik: Ekonomi untuk Kesejahteraan Rakyat, Edisi 2. Penerbit. Indeks, Jakarta.

Ponzetto, Giacomo. 2010. Asymetric Information and Trade Policy. Barcelona Economics Working Paper Series No. 514.

Ross, Jonathan F. (2016). The information content of accounting reports An information theory perspective. Information (Switzerland), 7(3). https://doi.org/10.3390/info7030048

Rumayya. 2015. Electoral Accountability of Local Government in Post-Decentralized Indonesia: Does Economy Matters? The University of Western Australia.

Scott, William R. 2003. Financial Accounting Theory.Second Edition. Canada: Prentice Hall. 
Sekaran, Uma dan Roger Bougle. (2016). Research Methods for Business, Seventh Edition. John Wiley \& Sons Ltd.

Sulaiman, Syarif Hidatullah. (2018). Akuntabilitas Electoral di Indonesia : Pengaruh kandungan informasi kinerja Pemerintah terhadap terpilihnya Petahana, Simposium Nasional Akuntansi XX1 Samarinda.

Tjenreng, MB. Zubakrum (2016). Pilkada Serentak. Penguatan Demokrasi di Indonesia, Pustaka Kemang, Depok.

Trounstine, Jessica. 2013. Information, Turnout, and Incumbency in Local Elections. Urban Affairs Review, Volume 49, No. 2.

Yulianti, Retno, Soemarso Slamet Raharjo dan Dodik Siswantoro. 2017. Accountability and Incumbent Reelection in Indonesian Local Government. Faculty of Economics and Business, Universitas Indonesia. International Research Journal of Business Studies Vol. 9 No. 3.

Zaller, John. 1992. The Nature and Origins of Mass Opinion. New York: Cambridge University Press. Zaller, John. 1996. The Myth of Massive Media Impact Revived: New Support for a Discredited Idea.dalam Political Persuasion and Attitude Change. editor Diana Carole Mutz, Paul M. Sniderman, Richard A. Brody.Michigan: Ann Arbor The University of Michigan Press. https://books.google.co.id/books?hl=id\&lr=\&id=nzfHh3spvQ0C\&oi=fnd\&pg=PA17

Zimmerman, J. (1977). The Municipal Accounting Maze: An Analysis of Political Incentives. Journal of Accounting Research. Studies on Measurement and Evaluation of the Economic Efficiency of Public and Private Nonprofit Institutions, 15, 107-144. 